\title{
PENYELESAIAN SENGKETA ANTARA BANK SHARÎ'AH DENGAN NASABAH BERMASALAH MELALUI BADAN ARBITRASE SHARÎ'AH NASIONAL (BASYARNAS) MENURUT UU NO. 30 TAHUN 1999
}

\author{
Sulistyowati \\ Sekolah Tinggi Agama Islam Negeri Kediri, Indonesia \\ E-mail: diajengsulis@yahoo.com
}

\begin{abstract}
This study deals with dispute settlement between Bank Syariah and its customers through the National Shari'ah Arbitration Board (BASYARNAS). It focuses to elaborate the procedures of dispute settlement between Bank Syari'ah and its customers of financing from the perspective of Islamic law according to Bill No. 30/1999 above law No. 30 year 1999. Based on procedures as mentioned in the bill with regard to arbitration and alternative dispute resolution, Basyarnas, in proofing and resolving cases, has fulfilled the procedures and satisfied the conflicting parties with justice, so there is no need to appeal and reconsideration. This means that Basyarnas has conducted dispute resolution according to the existing procedures. The dispute settlement has also been in accordance with the Qur'ân and other Islamic legal rules which consist of the principles of power and mandate applied by the arbitrator in deciding and resolving the dispute. The board—as an independent institution - has setttled the disputes on the basis of justice for all parties, rejected the act of bribery since the cost is measurable. In addition, Basyarnas also gives strong emphasis on the principle of equality, friendship, consistence and response-bility in resolving disputes.
\end{abstract}

Keywords: Dispute; arbitration; Basyarnas; Islamic law.

\section{Pendahuluan}

Perbankan sharî́ah dengan prinsip pokoknya yaitu profit and loss sharing (pembagian keuntungan dan kerugian) memiliki ketahanan yang cukup baik sebagai unit dalam sistem keuangan Indonesia, 
sehingga memeroleh kepercayaan dari masyarakat. ${ }^{1}$ Sebagian besar secara teori lslam berargumen bahwa bank sharî‘ah untuk menuju kepada tatanan institusi keuangan yang berlabel halal lslami, maka perbankan lslam dalam operasionalnya harus didasarkan pada nisbah bagi hasil, bukan berdasarkan bunga. ${ }^{2}$ Namun dalam praktiknya bank lslam sejak awal telah merasakan kesulitan dalam mengaplikasikan nisbah bagi hasil karena penuh risiko dengan tingkat ketidakpastian yang relatif besar terutama dalam bidang penyaluran dana (pembiayaan) sebagaimana fungsi dari perbankan. ${ }^{3}$

Pembiayaan merupakan kegiatan utama bank sebagai usaha memeroleh keuntungan dan salah satu kegiatan operasional bank yang senantiasa berhadapan dengan risiko dan pendapatan (return). Risiko merupakan ketidakpastian yang mengandung kemungkinan kerugian dalam bentuk harta atau kehilangan keuntungan di mana risiko tidak saja merugikan bank melainkan dapat juga merugikan masyarakat penyimpan dana pada khususnya dan pada umumnya semua stakeholder. ${ }^{4}$ Secara umum jenis risiko yang dihadapi oleh lembaga perbankan baik bank konvensional maupun sharî́ah hampir sama dan saling berkaitan yaitu risiko kredit (credit risk) dan risiko likuiditas (liquidity risk), risiko modal (capital risk), risiko operasional (operational risk) dan risiko tingkat suku bunga (interest risk). ${ }^{5}$

\footnotetext{
${ }^{1}$ Secara garis besar dalam praktiknya hubungan ekonomi secara sharî́ah ditentukan oleh adanya hubungan akad. Selain itu salah satu aspek penting dalam perbankan sharî‘ah adalah proses pembiayaan yang sehat. Menurut Undang-undang Republik Indonesia Nomor 10 tahun 1998 tentang Pembiayaan Berdasarkan Prinsip Sharı̂‘ah bahwa penyediaan uang atau tagihan yang dipersamakan dengan itu berdasarkan tujuan atau kesepakatan antara bank dengan pihak lain yang mewajibkan pihak yang dibiayai untuk mengembalikan uang atau tagihan tersebut setelah jangka waktu tertentu dengan jumlah atau bagi hasil. Sutan Remy Sjabdeini, Perbankan Islam dan Kedudukannya dalam Tata Hukum Perbankan Indonesia (Jakarta: PT. Pustaka Utama Grafita, 1999), 6.

2 Muhammad, Manajemen Bank Syariah (Yogyakarta: UPP AMPKPN, 2002), 191.

3 Bank sharî́ah memiliki peran dan fungsi yang sama sebagai suatu lembaga intermediasi yang mengarahkan dana dari masyarakat yang memiliki kelebihan dana dan kemudian menyalurkan dana tersebut kembali kepada masyarakat yang membutuhkan. Dalam hal ini penyalurran dana di bank sharî‘ah dalam bentuk sebuah fasilitas pembiayaan bukan kredit seperti halnya diperbankan konvensional. Lihat Edy Wibowo, Mengapa Memilih Bank Syariah (Jakarta: Ghalia, 2005), 57.

${ }^{4}$ Muhamad, Manajemen Dana Bank Syariah (Yogyakarta: Ekonisia, 2004), 113.

${ }^{5}$ Bank sharî‘ah secara langsung tidak akan menghadapi risiko tingkat suku bunga walaupun dalam lingkungan di mana berlaku dual banking system meningkatnya tingkat suku bunga di pasar konvensional dapat berdampak pada meningkatnya
} 
Namun risiko pembiayaan antara bank sharî‘ah dengan bank konvensional terdapat perbedaan yang signifikan, baik di tingkat risiko yang diterima oleh bank maupun nasabah. Keadaan inilah yang menjadi pemicu perbedaan (baik dari aplikasinya maupun aturan hukum) antara pembiayaan yang terjadi di bank sharî‘ ah dan kredit di bank konvensional. ${ }^{6}$

Risiko kredit atau pembiayaan berhubungan erat dengan menurunnya pendapatan yang merupakan akibat dari kerugian atas pembiayaan atau kredit pada umumnya risiko tersebut muncul, jika bank tidak bisa memeroleh kembali angsuran pokok atau bunga dari pinjaman yang diberikan kepada debitur. Oleh karena itu bank harus menggunakan fungsi pengawasan yang bersifat pencegahan terhadap permasalahan internal maupun eksternal, pencegahan dini merupakan tindakan preventif terhadap kemungkinan terjadinya hal-hal yang merugikan bank dalam pembiayaan sekaligus menghindari terjadinya praktik-praktik pembiayaan yang tidak sehat. ${ }^{7}$

Pencegahan dini dapat dilakukan dengan cara mengeliminir risiko yang datang dari berbagai faktor internal sekaligus sebagai alat pencegah yang mampu meminimalisir peluang terjadinya risiko dilengkapi dengan audit pada aspek pembiayaan sebagai alat kontrol pencegahan terjadinya risiko yang datang eksternal bank. Oleh karena itu, manajemen bank harus menggunakan semua perangkat operasionalnya agar mampu menjaga tingkat kesehatan bank yang bersinergi dengan peningkatan citra bank yang berdampak pada usaha peningkatan kepercayaan masyarakat terhadap bank. ${ }^{8}$

Selain penyempurnaan terhadap sisi kelembagaan, perlu juga memerhatikan sisi hukum sebagai landasan penyelenggaraannya. Hal ini untuk mengantisipasi munculnya berbagai macam permasalahannya dalam operasionalisasi. Penyelesaian sengketa dapat dilakukan melalui dua proses. ${ }^{10}$ Proses penyelesaian sengketa tertua melalui proses litigasi di dalam pengadilan, kemudian berkembang proses penyelesaian sengketa melalui kerja sama (kooperatif) atau

risiko likuiditas sebagai akibat adanya nasabah yang menarik dananya dari bank sharî‘ah ke bank konvensional. Zainul Arifin, Dasar-dasar Perbankan Syariah (Yogyakarta: YPPM, 1998), 69.

6 Juli Irmiyanto, Bank dan Lembaga Kenangan Lainnya (Jakarta: Media Ekonomia Publishing, FE. Trisakti, 1998), 12.

${ }^{7}$ Kasmir, Manajemen Perbankan (Jakarta: Raja Grafindo Persada, 2004), 65.

${ }^{8}$ Suyatno, Kelembagaan Perbankan (Jakarta: Gramedia, 1990), 33. 
musyawarah di luar pengadilan. ${ }^{9}$ Dengan perkembangan ekonomi dan bisnis sharî‘ah dewasa ini, tidak menutup kemungkinan akan adanya kecenderungan masyarakat atau pihak-pihak yang bersengketa memilih untuk menyelesaikan sengketa bisnisnya di lemabaga nonlitigasi baik itu Basyarnas atau arbitrase lainnya, daripada proses litigasi (sengketa di pengadilan) menunjukkan bahwa arbitrase lebih mengedepankan asas cepat dan sederhana dalam proses beracara dengan tidak mengesampingkan nilai-nilai keadilan subtantansial.

Penyelesaian sengketa perbankan sharî́ah di luar jalur pengadilan atau non-litigasi diselesaikan melalui Basyarnas sebagai alternatif penyelesaian sengketa dengan harapan melalui proses di luar pengadilan ini menghasilkan kesepakatan yang bersifat win-win solution. Prosesnya lebih efektif, cepat, bermartabat, dan terhindar dari kelambatan yang diakibatkan karena hal prosedural dan administratif, serta terhindar dari praktik penyuapan dan diselesaikan oleh para pakar mu'âmalah yang competable. Adapun keuntungan lain yang akan diperoleh apabila menggunakan penyelesaian masalah di Basyarnas secara komprehensif adalah terjaganya rahasia karena proses persidangan dan bahkan hasil keputusannya pun tidak dipublikasikan sehingga terbangunnya kebersamaan dan tetap rnenjaga hubungan baik antar-pihak yang bersengketa. ${ }^{12}$ Penyelesaian sengketa diluar pengadilan ini umumnya dinamakan dengan Alternative Dispute Resolution (ADR).

\section{Pengertian Basyarnas}

Arbitrase10 merupakan salah satu cara penyelesaian sengketa perdata di luar peradilan umum yang didasarkan pada perjanjian arbitrase yang dibuat secara tertulis oleh para pihak yang bersengketa.

\footnotetext{
9 Seperti diketahui bahwa penyelesaian sengketa perbankan sharî‘ah yang timbul dari aktiva produktif adalah penamaman dana bank sharî‘ah dalam rupiah maupun valuta asing dalam bentuk pembiayaan, piutang, gard, surat berharga sharî‘ah, penyertaan modal sementara, komitmen dan kontijensi pada transaksi rekening administratif serta sertifikat wadı̂'ah Bank Indonesia. Ahmad Yani, Hukum Arbitrase (Jakarta: Intermasa, 1998), 119.

10 Istilah arbitrase berasal dari Bahasa Belanda arbitrate, Bahasa Inggris arbitration, dan Bahasa Latin arbitrare yang berarti penyelesaian atau pemutusan sengketa oleh seorang hakim atau para hakim berdasarkan persetujuan bahwa mereka akan tunduk dan mentaati keputusan yang ditetapkan oleh hakim atau para hakim yang mereka pilih atau tunjuk tersebut.
} 
Adapun pengertian arbitrase sharî́ah ${ }^{11}$ adalah penyelesaian sengketa dengan cara arbitrase yang dilakukan dengan tuntunan sharî́ah. ${ }^{12}$

Basyarnas (Badan Arbitrase Sharî́ah Nasional) adalah perubahan dari nama Badan Arbitrase Muamalat Indonesia (BAMUI) yang merupakan salah satu wujud dari arbitrase lslam yang pertama kali didirikan di lndonesia atau suatu lembaga arbitrase nasional satusatunya yang menetapkan hukum lslam (sharî‘ah) yang berlaku terhadap penyelesaian sengketa mu'âmalah yang pendiriannya diprakarsai oleh Majelis Ulama Indonesia (MUI) tanggal 05 Jumadil Awal $1414 \mathrm{H}$ bertepatan dengan tanggal 21 Oktober $1993 .{ }^{13}$

Basyarnas sebuah wadah alternatif di luar pengadilan (non-litigasi) di dalam menyelesaikan perkara atau sengketa di perbankan sharî́ah dan Lembaga Keuangan Sharî̀ah (LKS) lainnya yang berdiri secara independen sebagai salah satu instrumen hukum yang menyelesaikan perselisihan para pihak, baik yang datang dari dalam lingkungan bank sharî'ah, asuransi sharî̀'ah maupun pihak lain yang memerlukannya, bahkan dari kalangan non-Muslim pun dapat memanfaatkan Basyarnas selama yang bersangkutan memercayai kredibilitasnya dalam menyelesaikan sengketa.

\section{Sejarah Basyarnas}

Badan Arbitrase berdasarkan sharî́ah Islam muncul dan berkembang karena maraknya kesadaran masyarakat Muslim terhadap pelaksanaan hukum Islam dan kebutuhan riil praktik peradilan perdata serta perkembangan kehidupan ekonomi keuangan umat Islam.

Dengan adanya fatwa-fatwa Dewan Sharî́ah Nasional di mana setiap bank sharî́ah atau lembaga keuangan sharîa dalam setiap produk akadnya harus mencatumkan klausul arbitrase, maka semua sengketa-sengketa yang terjadi antar-perbankan sharî‘ah atau lembaga keuangan sharî́ah dengan nasabahnya harus diselesaikan melalui Basyarnas.

\footnotetext{
11 Sharî‘ah adalah jalan lurus yang harus diikuti setiap Muslim atau ketentuanketentuan hukum yang beruhubungan dengan perbuatan manusia. Abdullah Yusuf Ali, Hukum Syariah (Jakarta: Rineka, 1992), 11.

12 Brosur BASYARNAS Tahun 2010.

13 Menurut SK. MUI No. Kep-09/MUI/XII/2003, 24 Desember 2003 bahwa Basyarnas (Badan Arbitrase Sharî‘ah Nasional) adalah lembaga ḩakam (Arbitrase Sharî́ah) satu-satunya di Indonesia yang berwenang dan memutuskan sengketa muamalah yang timbul dalam bidang perdagangan, keuangan, industri, jasa, dan lainnya.
} 
Peresmian Badan Arbitrase Muamalat Indonesia (BAMUI) dilangsungkan tanggal 21 Oktober 1993. Nama yang diberikan pada saat diresmikan adalah Badan Arbitrase Muamalat Indonesia (BAMUI). Peresmiannya ditandai dengan penandatanganan akta notaris oleh Dewan Pendiri, yaitu Dewan Pimpinan Majelis Ulama Indonesia (MUI) pusat yang diwakili KH. Hasan Basri dan H.S Prodjokusumo, masing-masing sebagai Ketua Umum dan Sekretaris Umum dewan pimpinan MUI. Sebagi saksi yang ikut menandatangani akta notaris masing-masing H.M. Soejono dan H. Zainulbahar Noor, SE (Dirut Bank Muamalat Indonesia) saat itu. BAMUI tersebut diketuai oleh H. Hartono Mardjono, SH sampai beliau wafat tahun 2003. Pada tanggal 22 April 1992, Dewan Pimpinan MUI mengundang rapat para pakar atau praktisi hukum atau cendekiawan Muslim termasuk dari kalangan Perguruan Tinggi guna bertukar pikiran perlu tidaknya dibentuk Arbitrase Islam. Setelah beberapa kali melakukan rapat, didirikanlah Badan Arbitrase Muamalat Indonesia (BAMUI) yang didirikan oleh Majelis Ulama Indonesia (MUI) tanggal 05 Jumadil Awal $1414 \mathrm{H}$ bertepatan dengan tanggal 21 Oktober tahun $1993 \mathrm{M}^{14}$

Dalam rekomendasi RAKERNAS MUI, tanggal 23-26 Desember 2002, menegaskan bahwa BAMUI adalah lembaga hukam (Arbitase Shar'`‘ah) satu-satunya di Indonesia dan merupakan perangkat organisasi MUI. Kemudian sesuai dengan hasil pertemuan antara Dewan Pimpinan MUI dengan Pengurus BAMUI tanggal 26 Agustus 2003 serta memerhatikan isi surat Pengurus BAMUI No.82/BAMUI/07/X/2003, tanggal 07 Oktobe2003, maka MUI dengan surat keputusannya No. Kep -09/MUI/XII/2003, tanggal 24 Desember 2003, menetapkan:

1. Mengubah nama Badan Arbitrase Mu'amalat Indonesia (BAMUI) menjadi Badan Arbitrase Sharî‘ ah Nasional (Basyarnas). ${ }^{15}$

2. Mengubah bentuk badan BAMUI dari yayasan menjadi badan yang berada di bawah MUI dan merupakan perangkat organisasi.

\footnotetext{
${ }^{14}$ Didirikannya oleh Majelis Ulama Indonesia (MUI), tanggal 05 Jumadil Awal 1414 $\mathrm{H}$ bertepatan dengan tanggal 21 Oktober 1993 M. Badan Arbitrase Muamalat Indonesia (BAMUI) didirikan dalam bentuk badan hukum yayasan sesuai dengan akta notaris Yudo Paripurno, SH Nomor 175 tanggal 21 Oktober 1993.

15 Badan Arbitrase Sharî‘ $a h$ Nasional (BASYARNAS) adalah perubahan dari nama Badan Arbitrase Muamalat Indonesia (BAMUI) yang merupakan salah satu wujud dari arbitrase Islam yang pertama kali didirikan di Indonesia.
} 
3. Dalam melaksanakan tugas dan fungsinya sebagai lembaga hukum, Basyarnas bersifat otonom dan independen.

Basyarnas berdiri secara otonom dan independen sebagai salah satu instrumen hukum yang menyelesaikan perselisihan para pihak, baik yang datang dari lingkungan bank sharî‘ah, asuransi sharî‘ $a h$, maupun pihak lain yang memerlukan bahkan dari kalangan nonMuslim pun dapat memanfaatkan Basyarnas selama yang bersangkutan memercayai cara bekerjanya dalam menyelesaikan sengketa.

Kehadiran Basyarnas sangat diharapkan oleh umat Islam Indonesia, bukan saja karena dilatari oleh kesadaran dan kepentingan umat untuk melaksanakan sharî‘ah Islam, melainkan juga lebih dari itu adalah menjadi kebutuhan riil sejalan dengan perkembangan kehidupan ekonomi dan keuangan umat. Karena itu, tujuan didirikannya Basyarnas sebagai badan permanen dan independen yang berfungsi menyelesaikan kemungkinan terjadinya sengketa mu'âmalah yang timbul dalam hubungan perdagangan, industri keuangan, jasa di kalangan umat Islam.

Berdirinya Basyarnas ini tidak terlepas dari konteks perkembangan kehidupan sosial ekonomi umat Islam. Konteks ini jelas dihubungkan dengan berdirinya Bank Muamalat Indonesia dan Bank Perkreditan Rakyat Sharî́ah (BPRS) serta Asuransi Takaful yang lebih dulu lahir. ${ }^{16}$

Badan Arbitrase Sharî́ah Nasional (Basyarnas) sebagai lembaga permanen yang didirikan MUI berwenang antara lain:

a. Menyelesaikan secara adil dan cepat sengketa mu'amalah (perdata) yang timbul dalam bidang perdagangan, keuangan, industri, jasa dan lain-lain di mana para pihak sepakat secara tertulis untuk menyerahkan penyelesaianya kepada Basyarnas sesuai dengan peraturan prosedur Basyarnas. ${ }^{17}$

b. Memberikan pendapat yang mengikat atas permintaan para pihak tanpa adanya sesuatu sengketa mengenai persoalan tertentu dalam suatu perjanjian. ${ }^{18}$

16 Lahirnya Badan Arbitrase Sharî‘ ah Nasional ini, menurut Prof. Maryam Darus Badrul Zaman, sangat tepat karena melalui badan arbitrase tersebut, sengketasengketa bisnis yang operasionalnya memergunakan hukum Islam dapat diselesaikan dengan memergunakan hukum Islam. Maryam Badrul Zaman, Arbitrase Islam di Indonesia (Jakarta: Rineka 1994), 64

17 Ibid.

18 Basyarnas dapat memberikan suatu rekomendasi atau pendapat hukum (binded advice), dan prosedur arbitrase. Profil dan Prosedur Basyarnas, 2008, 10. 
c. Apabila jalur arbitrase tidak dapat menyelesaikan perselisihan, maka lembaga peradilan adalah jalan terakhir sebagai pemutus perkara tersebut dan hakim harus memerhatikan rujukan yang berasal dari arbiter yang sebelumnya telah menangani kasus tersebut sebagai bahan pertimbangan dan untuk menghindari lamanya proses penyelesaian.

\section{Mekanisme Operasional Beracara Melalui Basyarnas}

Mengenai prosedur berperkara di Basyarnas telah diatur dengan sistematis sejak mulai didirikan Badan Arbitrase Muamalat Indonesia (BAMUI) secara garis besar aturan tersebut dituangkan dalam peraturan prosedur BAMUI yang diberlakukan sejak tanggal 21 Oktober 1993. Beberapa tambahan yang terjadi setelahnya yang hanya bersifat teknis untuk menyempurnakan aturan yang telah ditetapkan sebelumnya, sepanjang aturan tersebut tidak bertentangan dengan Undang-undang No. 30 Tahun 1999 tentang arbitrase dan alternatif penyelesaian sengketa.

Adapun prosedur penyelesaian sengketa melalui Basyarnas dimulai dengan penyerahan secara tertulis oleh para pihak yang sepakat untuk menyelesaikan persengketaan melalui Basyarnas sesuai dengan peraturan prosedur yang berlaku, pihak yang bersengketa sepakat akan menyelesaikan persengketaan mereka dengan istilah perdamaian tanpa ada suatu persengketaan berkenaan dengan perjanjian atas permintaan para pihak tersebut. Kesepakatan ini dicantumkan dalam klausul arbitrase. $^{19}$

\section{Prosedur Administrasi}

Prosedur arbitrase dimulai dengan didaftarkannya surat permohonan para pihak yang bersengketa kepada sekretaris Basyarnas. Surat permohonan harus memuat sekurang-kurangnya: nama lengkap, tempat tinggal kedua belah pihak atau para pihak, ${ }^{20}$ uraian singkat tentang problem sengketa, ${ }^{21}$ dan apa yang dituntut. Pada surat permohonan harus dilampirkan Salinan dari naskah

19 Perjanjian arbitrase merupakan suatu kesepakatan berupa klausul arbitrase yang tercantum dalam suatu perjanjian tertulis yang dibuat para pihak sebelum timbul sengketa atau suatu perjanjian arbitrase tersendiri yang dibuat para pihak setelah timbul sengketa.

${ }^{20}$ Harus mencantumkan alamat kantor atau tempat tinggal terakhir kantor dagang yang dinyatakan dengan tegas dalam klausul arbitrase. Lihat Achmad Djauhari, "Penyelesaian Sengketa Bisnis (Perbankan) Sharî‘ah" (Surabaya: BI, 2012), 58.

${ }^{21}$ Berkas juga memuat uraian singkat tentang problem sengketa dan juga apa yang dituntut. Ibid. 
kesepakatan yang secara khusus menyerahkan pemutusan sengketa kepada Basyarnas.

Surat perjanjian yang memuat klausul arbitrase adalah ketentuan yang menetapkan bahwa sengketa-sengketa yang timbul dari perjanjian tersebut akan diputus Basyarnas apabila surat permohonan diajukan oleh juru kuasa, maka surat kuasa khusus untuk mengajukan permohonan tersebut harus dilampirkan.

Pada dasarnya pengadilan tidak berwenang untuk mengadili sengketa para pihak yang telah terikat dalam perjanjian arbitrase. Dengan adanya suatu perjanjian arbitrase tertulis, maka perjanjian itu memadukan hak para pihak untuk mengajukan penyelesaian sengketa atau beda pendapat yang termuat dalam perjanjiannya ke Pengadilan Agama. Dalam hal ini Pengadilan Agama menolak dan tidak akan campur tangan di dalam ranah penyelesaian sengketa yang telah ditetapkan melalui arbitrase dan dalam hal-hal tertentu yang ditetapkan melalui arbitrase kecuali dalam hal-hal tertentu yang ditetapkan undang-undang.

Surat perjanjian tertulis bahwa para pihak yang memilih penyelesaian sengketa melalui Basyarnas hendaklah ditandatangani oleh para pihak di mana di dalam penyelesaian tersebut disebutkan bahwa para pihak memilih penyelesaian sengketa melalui arbitrase sharî'ah dan perjanjian itu harus dibuat dalam bentuk akta notaris. Para pihak boleh mengajukan tuntutan ingkar jika terdapat cukup bukti autentik yang menimbulkan keraguan bahwa arbiter yang ditunjuk akan melakukan tugasnya tidak secara netral dan akan berpihak kepada salah satu pihak dalam mengambil keputusan.

Pendaftaran tidak akan diterima oleh sekretaris apabila biaya-biaya pendaftaran, administrasi dan atau pemeriksaan sebagaimana ditetapkan dalam peraturan tentang biaya arbitrase belum dibayar lunas oleh pemohon. Apabila para pihak tidak mampu membayar biaya-biaya pendaftaran, administrasi atau pemeriksaan yang dapat dibuktikan dengan surat keterangan resmi sekurang-kurangnya dari Kepala Desa atau Lurah setempat, maka ketua BAMUI dapat menetapkan kebijaksanaannya. ${ }^{22}$ Perhitungan tenggang waktu itu sesuai dengan peraturan prosedur yang berlaku dan perhitungan waktu atas segala penerimaan pemberitahuan. Surat-menyurat atas usul dianggap telah diterima apabila secara nyata disampaikan ke alamat tempat tinggal atau alamat tempat kediaman atau dikirimkan ke

22 Ahmad Nafis, Wawancara, Surabaya 24 September 2012. 
alamat kantor dagang atau dikirim ke alamat terakhir tempat kediaman atau alamat terakhir dagang atau tempat kedudukan yang telah dinyatakan dengan tegas dalam klausul arbitrase. ${ }^{23}$

Penerimaan dianggap terhitung pada hari disampaikan. Adapun perhitungan tenggang waktu mulai berjalan ialah setelah penerimaan. Jika hari terakhir dalam waktu tersebut hari libur resmi, perhitungan tenggang waktu adalah hari berikut dari hari libur yang dimaksud. Berikut ini akan diberikan persyaratan dan contoh-contoh aplikasi beracara melalui Basyarnas, sebagai berikut:

Persyaratan Pendaftaran Permohonan Arbitrase: pemohon mendaftarkan permohonan arbitrase ke sekretaris Basyarnas ${ }^{24}$ dengan dilampiri: surat permohonan arbitrase, surat kuasa khusus dari Pemohon (bila ada), surat bukti perjanjian antara para pihak yang ada klausul arbitrase, surat bukti lainnya yang dianggap perlu yang sudah dimaterai di kantor pos, surat daftar bukti, membayar biaya register permohonan arbitrase, dan selanjutnya Basyarnas akan memberikan nomor register perkara.

Kemudian surat permohonan arbitrase dan bukti diajukan kepada ketua oleh sekretaris. Setelah berkas diteliti dan sudah lengkap permohonan arbitrase, kemudian ketua menunjuk arbiter tunggal atau majelis arbiter dengan surat ketetapan. Salinan berkas permohonan arbitrase diserahkan kepada masing-masing Majelis Arbiter yang akan bersidang. Kemudian surat permohonan Arbitrase diserahkan kepada termohon dalam waktu 14 (empat belas) hari untuk menjawab secara tertulis atas permohonan arbitrase dari pemohon memanggil para pihak untuk sidang pertama.

Selama belum dijatuhkan putusan, pemohon dapat mencabut permohonannya. Apabila sudah ada jawaban dari termohon, maka pencabutan tersebut hanya diperbolehkan dengan persetujuan termohon. Apabila permohonan pencabutan itu dilakukan oleh pemohon sebelum ketua Basyarnas menunjuk arbiter tunggal atau arbiter majelis dan panggilan untuk menghadap sidang belum dikeluarkan, maka seluruh biaya pemeriksaan dikembalikan kepada pemohon. Apabila pemeriksaan oleh arbiter tunggal atau arbiter majelis sudah dimulai, maka dari biaya-biaya yang telah dibayar oleh

23 Rifyal Ka'bah, Penyelesaian Sengketa Bisnis Syariah: Sebuah Kewenangan Baru Peradilan Agama (Jakarta: Fakultas Hukum Universitas Yarsi, 2007), 112.

${ }^{24}$ Djauhari, "Penyelesaian Sengketa Perbankan Sharî‘ah", di Bank Indonesia Jawa Timur, 4 Desember 2012. 
pemohon akan dikembalikan sebagian menurut ketetapan Ketua Basyarnas sebagaimana yang dianggap pantas. ${ }^{25}$

\section{Sikap Basyarnas terhadap Permohonan}

Basyarnas akan menyatakan permohonan tidak dapat diterima, apabila perjanjian yang menyerahkan pemutusan sengketa kepada Basyarnas atau klausul arbitrase ${ }^{26}$ dianggap tidak cukup untuk dijadikan dasar kewenangan Basyarnas untuk memeriksa sengketa yang diajukan. Pernyataan tentang tidak dapat diterimanya permohonan dilakukan dengan sebuah penetapan yang dikeluarkan oleh Ketua Basyarnas selambat-lambatnya dalam empat belas hari terhitung sejak tanggal pendaftaran permohonan. ${ }^{27}$

Pernyataan tentang tidak dapat diterima permohonan juga dapat dilakukan oleh arbiter tunggal arbiter majelis yang telah ditunjuk dalam hal pemeriksaan telah mulai. Penetapan tentang tidak dapat diterima permohonan yang dikeluarkan oleh ketua disampaikan kepada pihak yang bersangkutan selambat-lambatnya dalam waktu empat belas hari terhitung tanggal penetapan. Seluruh biaya yang telah dibayar pemohon dikembalikan, kecuali biaya pendaftaran administrasi sebesar Rp. 20.000, bila permohonan dinyatakan tidak dapat diterima oleh ketua Basyarnas dan Apabila pemyataan tidak dapat diterima diputus oleh arbiter tunggal atau arbiter majelis, maka seluruh biaya tidak dikembalikan.

\footnotetext{
${ }^{25}$ Ahmad Nafis, Wawancara, Surabaya 11 Oktober 2012.

${ }^{26}$ Dalam praktik perjanjian untuk penyelesaian sengketa perdata menggunakan sistem arbitrase dengan menggunakan dua 2 cara yakni: pactum de compromittendo yakni kesepakatan penunjukan arbitrase tertulis oleh kedua belah pihak sejak terjadinya penanda tanganan perjanjian, kesepakatan penunjukkan arbitrase secara tertulis ini dapat disatukan dengan naskah pokok perjanjian dan dapat pula dipiosahkan namun tetap menjadi satu kesatuan dengan perjanjian pokok, yang kedua dengan acta compromis kesepakatan penunjukaan arbitrase secara tertulis oleh kedua belah pihak setelah mereka bersengketa, jadi kedua belah pihak dalam keadaan sedang sengketa kemudian sepakat menyelesaikan sengketanya melalui arbitrase, Djauhari, "Penyelesaian Sengketa Bisnis (Perbankan) Sharî'ah" 4 Desember 2012 di Gedung Bank Indonesia Jawa Timur.

${ }^{27}$ Ahmad Taqrir (Ketua Basyarnas Jawa Timur), Wawancara, Surabaya 19 September 2012.
} 
1. Permohonan

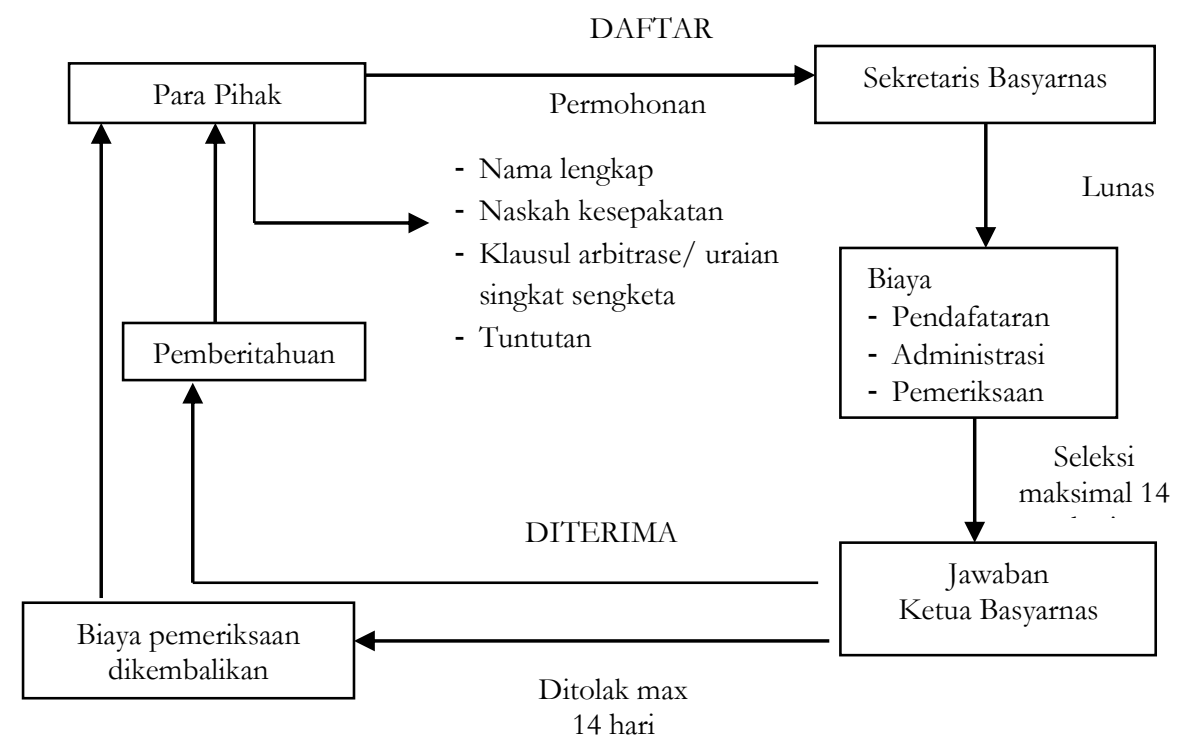

\section{Penetapan Arbiter Tunggal atau Arbiter Majelis}

Apabila perjanjian yang menyerahkan pemutusan sengketa kepada Basyarnas atau klausul arbitrase dianggap sudah mencukupi, maka ketua Basyarnas menetapkan dan menunjuk arbiter tunggal atau arbiter majelis ${ }^{28}$ yang akan memeriksa dan memutus sengketa dan sekaligus memerintahkan untuk menyampaikan salinan surat permohonan kepada termohon disertai perintah untuk menanggapi permohonan tersebut dan memberikan jawabannya selambatlambatnya dalam waktu 30 hari terhitung sejak tanggal diterimanya salinan surat permohonan dan surat panggilan. Salinan surat permohonan dan perintah untuk menanggapi serta memberikan jawabannya secara tertulis oleh termohon harus sudah disampaikan kepada termohon selambat-lambatnya delapan hari sesudah

\footnotetext{
28 Penunjukan arbiter ada dua cara (Pasal 1 angka 7 UU. No. 30 tahun 1999) yakni dengan masing-masing pihak menunjuk seorang sebagai arbiter (yang mereka percaya dan dapat memutus perkaranya secara adil) kemudian kedua orang arbiter tersebut menunjuk seorang arbiter ketiga sebagai ketua majelis, majelis arbiter inilah yang memeriksa, mengadili dan memutuskan perkara, kedua para pihak sepakat menyerahkan penunjukkan arbiter/arbiter majelis kepada pimpinan/ketua lembaga/ badan arbitrase. Djauhari, "Penyelesaian Sengketa Bisnis (Perbankan) Sharî‘ah" (Surabaya: BI, 2012).
} 
penetapan/penunjukan arbiter tunggal atau arbiter majelis. Adapun persyaratan untuk menjadi arbiter di Basyarnas ${ }^{29}$ antara lain: cakap melakukan tindakan hukum, minimal berumur 35 tahun, dan tidak memiliki hubungan keluarga sedarah sampai dengan derajat kedua dengan salah satu pihak bersengketa, tidak mempunyai kepentingan finansial atau kepentingan lain atas putusan arbitrase, memiliki pengalaman serta menguasai secara aktif di bidangnya minimal 15 tahun, bukan jaksa, hakim panitera dan pejabat peradilan lainnya.

Ketentuan lebih lanjut bahwa selain ada anggota-anggota arbiter tetap dalam Basyarnas juga terdapat anggota arbiter tidak tetap yaitu:

1. Beragama lslam yang taat menjalankan agamnya dan tidak terkena larangan berdasarkan peraturan perundang-undangan yang berlaku.

2. Ahli dalam ilmu, baik ilmu murni maupun terapan dan telah mempunyai pengalaman sekurang-kurangnya 10 tahun dalam bidangnya.

3. Memiliki integritas, kredibilitas serta nama baik di masyarakat.

4. Meyatakan setuju dan menerima segala ketentuan yang ada dan peraturan prosedur beracara yang berlaku di dalam Basyarnas.

5. Mengisi dan menandatangani formulir isian yang disiapkan oleh badan pengurus dan siap untuk dilantik sebagai arbiter Basyarnas.

Adapun berakhirnya masa keanggotaan sebagai arbiter dikarenakan meninggal dunia, atas permintaan sendiri, menduduki jabatan yang berdasarkan peraturan perundang-undangan yang berlaku dilarang untuk menjadi arbiter, atau diberhentikan (dengan alasan karena tidak lagi memenuhi persyaratan sebagai arbiter dan atau melakukan perbuatan yang tercela dilihat dari sudut pandang agama lslam. ${ }^{30}$

Adapun tugas pokok arbiter adalah sebagai berikut memeriksa dan memberikan putusan arbitrase dalam jangka waktu yang telah ditentukan (menurut pasal 48 paling lama 180 hari sejak penunjukkan atau pengangkatannya), bersikap independen dalam menjalankan tugasnya demi mencapai suatu putusan yang adil dan cepat bagi para pihak yang berbeda pendapat, berselisih paham maupun yang bersengketa.

29 Syarat dan tugas arbiter dalam pasal 12 UU No. 30 tahun 1999, Jakarta: Basyarnas 2005.

30 Dewi Nurul Musjtari, Penyelesaian Sengketa dalam Praktek Perbankan Syariah (Yogyakarta: Parama Publishing, 2012), 210. 
Dalam hal para pihak datang menghadap pada hari yang telah ditetapkan arbiter tunggal atau arbiter majelis harus terlebih dahulu mengusahakan perdamaian antara para pihak yang bersengketa (pasal 45 ayat 1$)$

Apabila usaha mendamaikan itu berhasil maka arbiter tunggal atau arbiter majelis membuat suatu akta perdamaian yang final dan mengikat para pihak dan memerintahkan para pihak untuk memenuhi ketentuan perdamaian tersebut.

Tugas arbiter berakhir sebagaimana diatur dalam pasal 37 Undang-Undang No. 30 Tahun 1999 adalah:

1. Apabila putusan mengenai sengketa telah diambil.

2. Jangka waktu yang telah ditentukan dalam perjanjian arbitrase atau sesudah diperpanjang oleh para pihak telah dilampaui.

3. Para pihak sepakat untuk menarik kembali penunjukkan arbiter.

Penetapan arbiter tunggal atau arbiter majelis dilakukan oleh ketua Basyarnas berdasarkan klausul arbitrase atau apabila tidak disebutkan yang demikian, ditetapkan berdasarkan berat ringannya sengketa. Arbiter yang telah ditunjuk oleh Ketua Basyarnas dipilih dari para anggota dewan arbiter yang telah terdaftar pada Basyarnas. Namun demikian, dalam hal yang sangat diperlukan karena pemeriksaan memerlukan suatu keahlian yang khusus, maka ketua Basyarnas berhak menunjuk seorang ahli dalam bidang khusus yang diperlukan untuk menjadi arbiter

Apabila salah satu atau kedua belah pihak yang bersengketa mempunyai keberatan terhadap arbiter yang telah ditunjuk oleh Ketua Basyarnas dengan adanya cukup bukti autentik yang menimbulkan keraguan bahwa arbiter atau arbiter majelis yang ditunjuk akan melakukan tugasnya tidak secara bebas, adil dan akan berpihak ke salah satu pihak bersengketa dalam mengambil keputusan selambatlambatnya dalam sidang pemeriksaan pertama. Hal keberatan tersebut telah diajukan oleh pihak yang bersangkutan disertai alasan-alasannya berdasar hukum. Para pihak dapat mengajukan permohonan pembatalan apabila putusan tersebut diduga mengandung unsur-unsur sebagai berikut.

1. Surat dokumen yang diajukan dalam pemeriksaan setelah putusan dijatuhkan diakui palsu atau dinyatakan palsu,

2. Setelah putusan diambil ditemukan dokumen yang bersifat menntukan yang disembunyikan oleh pihak lawan atau, 
3. Putusan diambil dari hasil tipu muslihat yang daikui oleh salah satu pihak dalam pemeriksaan sengketa.

Segera setelah selesainya sidang pertama pemeriksaan atau selambat-lambatnya dalam waktu tujuh hari arbiter tunggal atau arbiter majelis meneruskan keberatan itu kepada ketua Basyarnas dan selambat-lambatnya dalam waktu tiga hari ketua Basyarnas harus sudah memberikan penetapan apakah keberatan itu diterima atau ditolak berikut alasan-alasannya. Bila keberatan diterima, maka ketua Basyarnas dalam penetapan yang sama menunjuk arbiter lain. Adanya keberatan terhadap arbiter yang telah ditunjuk oleh Ketua Basyarnas yang diajukan oleh satu atau kedua belah pihak, tidak mengurangi kewajiban termohon untuk memberikan jawabannya secara tertulis sebagaimana yang telah ditentukan ${ }^{31}$.

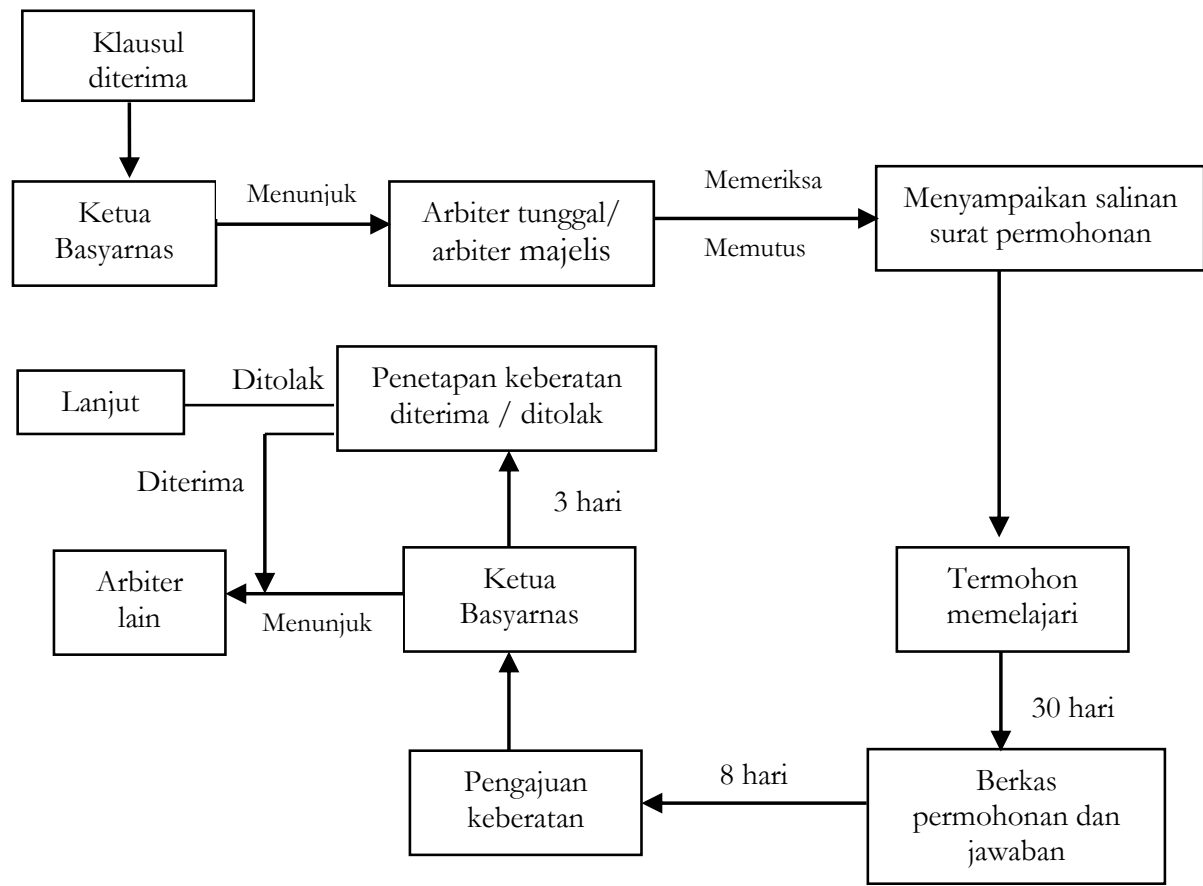

31 Ibid., 212. 


\section{Acara Pemeriksaan}

Pemeriksaan persidangan dilakukan di tempat kedudukan Basyarnas kecuali ada persetujuan dari kedua belah pihak pemeriksaan dapat dilakukan di tempat lain. Putusan harus diambil dan dijatuhkan di tempat kedudukan Basyarnas. Selama proses dan pada setiap tahap pemeriksaan berlangsung arbiter tunggal atau arbiter majelis harus memberi perlakuan dan kesempatan yang sama sepenuhnya kepada masing-masing pihak untuk membela dan memertahankan kepentingannya. Baik atas pendapat sendiri maupun atas permintaan salah satu pihakarbiter tunggal atau arbiter majelis dapat melakukan pemeriksaan dengan mendengar keterangan saksi, termasuk saksi ahli dan pemeriksaan secara lisan di antara para pihak. Setiap bukti atas dokumen yang disampaikan salah satu kepada arbiter tunggal atau arbiter majelis, salinannya harus diberikan kepada pihak lawan. Tata cara pemeriksaan dilakukan secara langsung dan tertulis di depan persidangan yang ditetapkan, untuk itu tanpa mengurangi kebolehan pemeriksaan secara lisan. Pemeriksaan terdiri atas tahap jawab menjawab (replik duplik), pembuktian dan putusan yang pentahapannya ditentukan berdasarkan kebijaksanaan arbiter tunggal atau arbiter majelis.

Pemeriksaan pokok sengketa dilanjutkan apabila usaha perdamaian tidak berhasil, selanjutnya para pihak diberi kesempatan terakhir kalinya untuk menjelaskan secara tertulis pendirian masingmasing serta mengajukan bukti yang dianggap perlu untuk menguatkan pendiriannya dalam jangka waktu yang ditetapkan oleh arbiter atau majelis arbitrase, jika diperlukan dapat dimintakan penjelasan tambahan dari para pihak secara tertulis dokumen atau bukti lainnya yang dianggap perlu dalam jangka waktu yang ditentukan oleh arbiter atau mejelis arbiter.

Pemeriksaan atas sengketa harus diselesaikan dalam waktu paling lama 180 hari sejak arbiter atau arbiter majelis terbentuk. Jika diperlukan maka jangka waktu ini dapat diperpanjang, mengenai biaya pemanggilan dan perjalanan saksi atau saksi ahli dibebankan kepada pihak yang meminta, apabila pemerikasaan sengketa telah selesai, maka pemerikasaan ditutup dan ditetapkan hari sidang untuk mengucapkan putusan arbitrase, putusan diucapkan dalam waktu paling lama 30 hari sejak pemeriksaan ditutup. 
Pemeriksaan

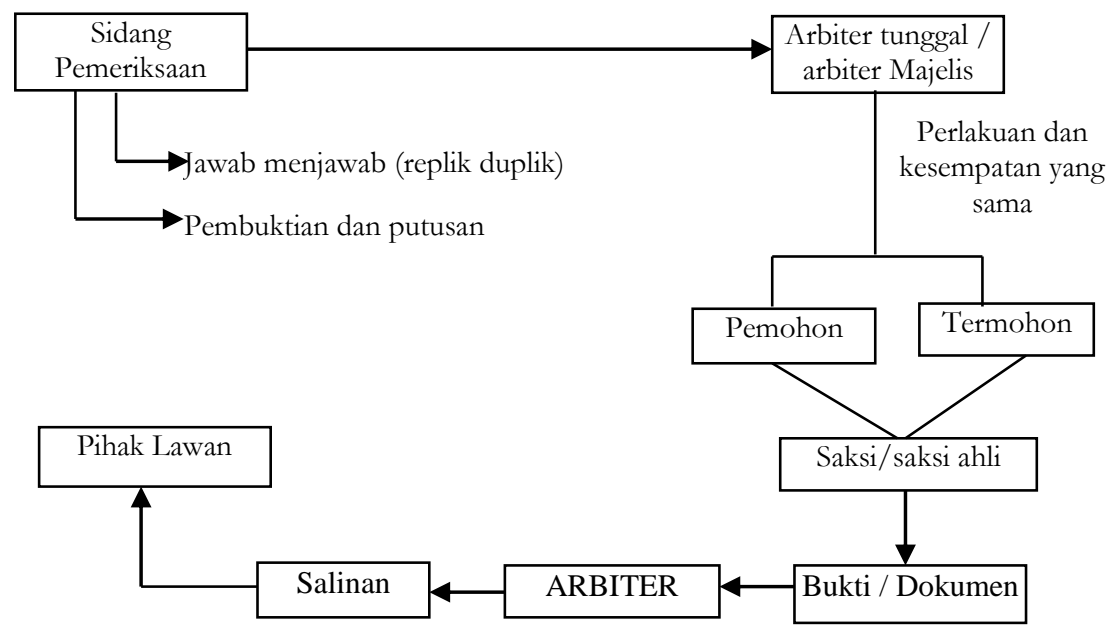

\section{Jawaban Termohon dan Tenggang Waktu}

Segera setelah diterimanya jawaban dari termohon atas perintah arbiter tunggal atau arbiter majelis. Salinan dari jawaban tersebut diserahkan kepada pemohon. Bersamaan dengan itu arbiter tunggal atau arbiter majelis memerintahkan kepada para pihak menghadap di muka sidang arbitrase pada tanggal yang ditetapkan, selambatlambatnya dalam waktu empat belas hari, terhitung sejak tanggal dikeluarkannya perintah itu, dengan pemberitahuan bahwa mereka boleh mewakilkan kepada kuasa dengan surat kuasa khusus. Apabila termohon, setelah lewatnya waktu tiga puluh hari tidak menyampaikan jawabannya, maka arbiter tunggal atau ketua arbiter majelis akan memerintahkan pemanggilan para pihak sebagaimana ketentuan yang berlaku

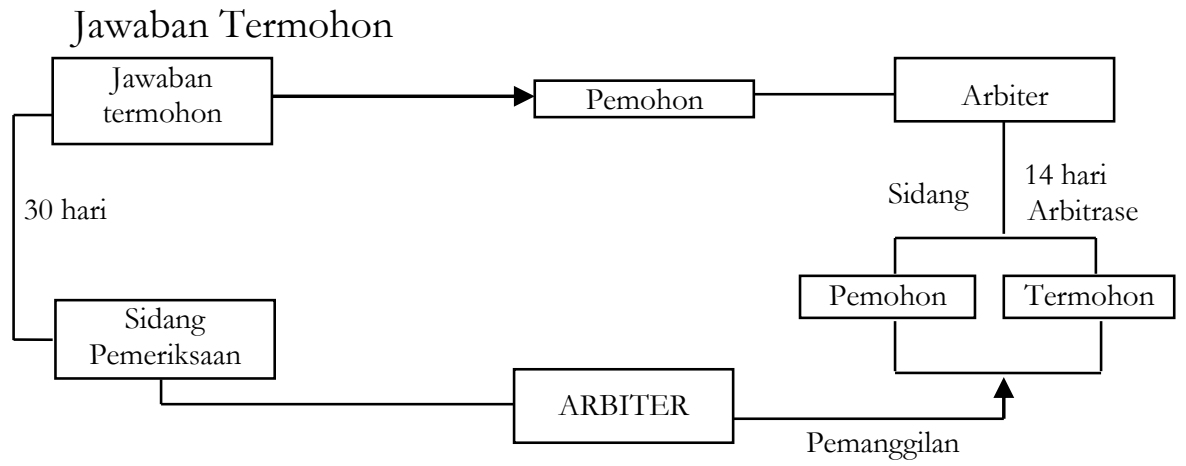




\section{Tuntutan Balasan}

Dalam jawabannya, atau paling lambat pada hari sidang pertama pemeriksaan, termohon dapat mengajukan suatu tuntutan balasan (reconventie). Terhadap bantahan yang diajukan termohon, pemohon dapat mengajukan jawaban yang dibarengi dengan tambahan tuntutan (additional claim) asal hal itu mempunyai hubungan erat dan langsung dengan pokok yang disengketakan serta termasuk menjadi yurisdiksi Basyarnas. Tuntutan-tuntutan dari masing-masing pihak terhadap pihak lainnya, akan diperiksa dan diputus oleh arbiter tunggal atau arbiter majelis bersama-sama dan sekaligus dalam suatu putusan. Apabila pada hari yang telah ditetapkan, pemohon tanpa suatu alasan yang sah tidak datang menghadap, sedangkan ia telah dipanggil secara patut, maka arbiter tunggal atau arbiter majelis akan menggugurkan permohonan pemohon.

Apabila pada hari yang telah ditetapkan itu, termohon tanpa suatu alasan yang sah, sedangkan ia telah dipanggil secara patut tidak datang menghadap, maka arbiter tunggal atau ketua arbiter majelis memerintahkan supaya dipanggil lagi untuk terakhir kali, guna menghadap di muka sidang pada waktu kemudian, yang ditetapkan selambat-lambatnya dalam waktu empat belas hari sejak dikeluarkannya perintah itu. Apabila pada hari yang telah ditetapkan lagi itu termohon tanpa suatu alasan yang sah tidak juga datang menghadap, maka pemeriksaan akan diteruskan tanpa hadirnya termohon dan tuntutan pemohon akan dikabulkan, kecuali tuntutan itu oleh arbiter tunggal atau arbiter majelis dianggap tidak berdasarkan hukum atau keadilan. Adapun putusan ${ }^{32}$ arbiter tunggal atau arbiter majelis dalam waktu empat belas hari setelah isi putusan diberitahukan kepadanya, termohon berhak mengajukan perlawanan (verstek). Perlawanan diajukan dengan cara yang sama seperti yang berlaku untuk mengajukan permohon perlu membayar biaya-biaya pendaftaran, administrasi dan pemeriksaan. Apabila pada hari sidang pemeriksaan perlawanan yang telah ditetapkan oleh Basyarnas

\footnotetext{
32 Putusan arbitrase bersifat final and binding. Artinya putusan arbiter majelis tersebut bersifat final sehingga tidak terbuka adanya upaya hukum (banding maupun kasasi) dan karenanya putusan tersebut bersifat mengikat, dan putusan arbitrase memiliki kekuatan eksekutorial artinya apabila ternyata para pihak dan atau yang kalah tidak dengan suka rela (tidak legowo) melaksanakan isi putusan arbitrase maka pihak yang menang hanya tinggal mohon eksekusi ke pengadilan negeri atau pengadilan agama dan tidak ada proses atau pemeriksaan ulang lagi. Djauhari, "Sengketa Bisnis (Perbankan) Sharî‘ah", 10.
} 
pelawan meskipun telah dipanggil secara sah tidak datang maka arbiter tunggal atau arbiter majelis akan menguatkan putusan. Apabila kedua belah pihak datang menghadap, maka pemeriksaan dilakukan dari permulaan sesuai ketentuan-ketentuan yang berlaku. ${ }^{33}$ Pada dasarnya proses penyelesaian sengketa melalui sistem arbitrase adalah mutatis-mutandis dengan penyelesaian perkara perdata di pengadilan negeri maupun pengadilan agama, secara teori para pihak yang bersengketa dapat menentukan prosedur beracara tersendiri (hal demikian tidak dimungkinkan untuk $\mathrm{PA} / \mathrm{PN}$ ) namun hal demikian tidaklah mudah pelaksanaannya.

Tuntutan Balasan

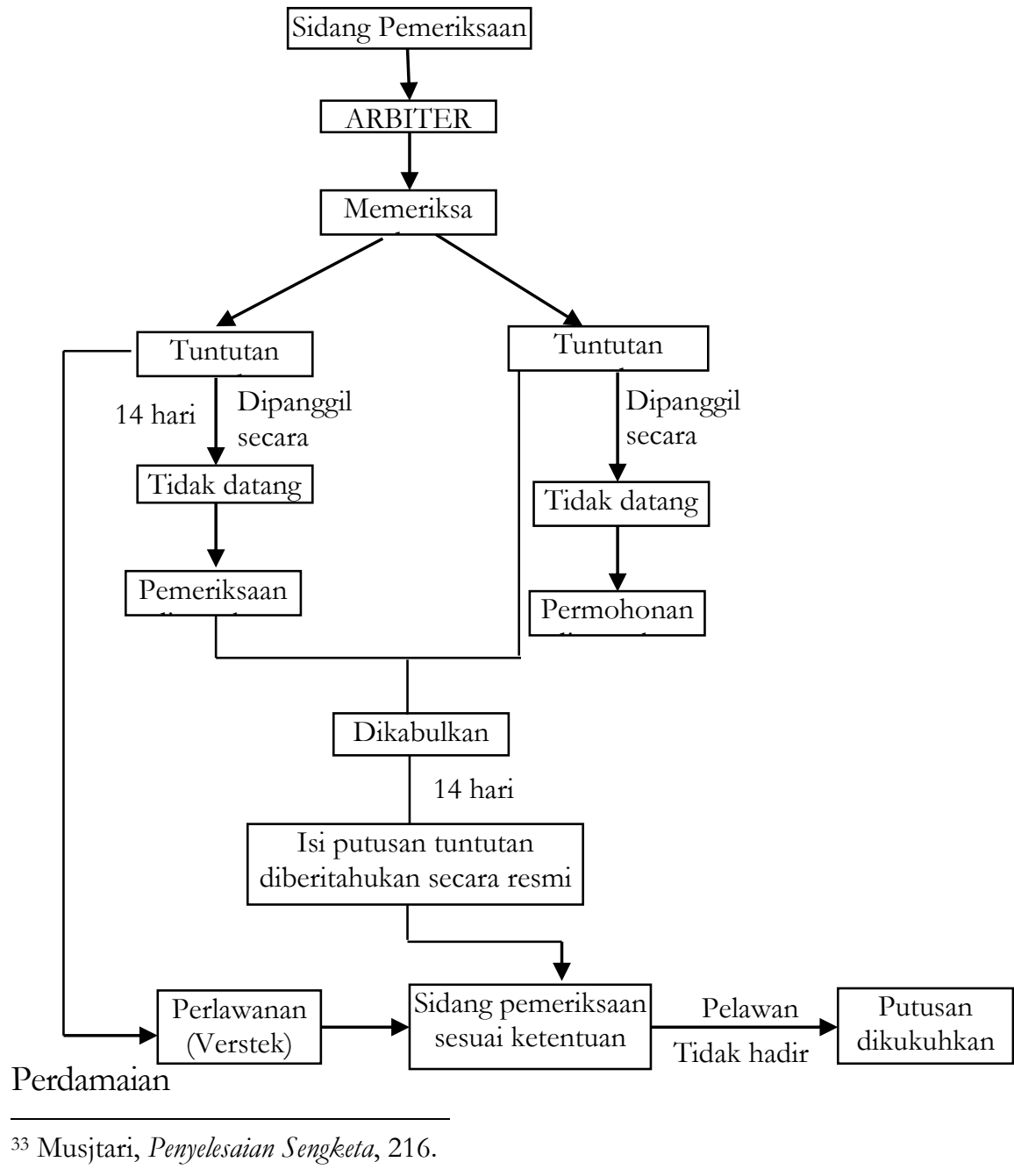


Terlebih dahulu arbiter tunggal atau arbiter akan mengusahakan tercapainya perdamaian. Apabila usaha tersebut berhasil, maka arbiter tunggal atau arbiter majelis akan membuatkan akte perdamaian dan menghukum kedua belah pihak untuk memenuhi dan menaati perdamaian tersebut. Apabila perdamaian tidak berhasil, ${ }^{34}$ maka arbiter tunggal atau arbiter majelis akan meneruskan perneriksaan terhadap sengketa yang dimohon.

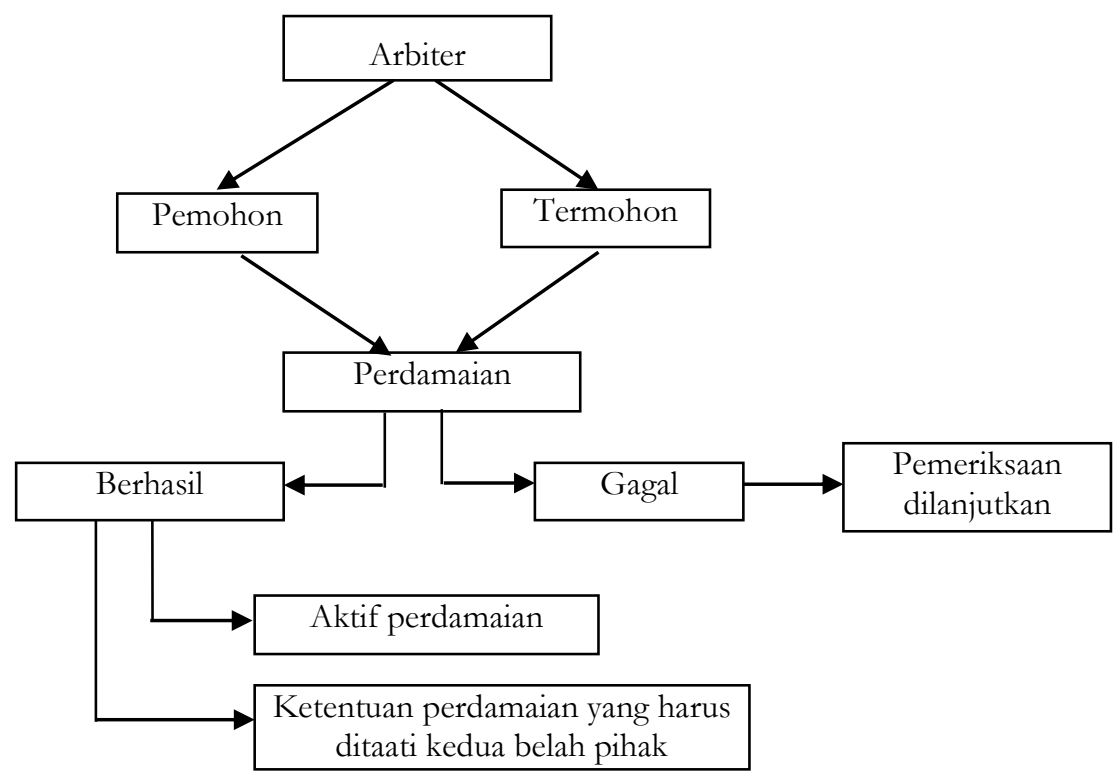

Pembuktian dan saksi/ahli

Para pihak dipersilahkan untuk menjelaska dalil pendirian masingmasing serta mengajukan bukti yang dianggap perlu untuk menguatkannya. Apabila dianggap perlu, arbiter tunggal atau arbiter dapat memanggil saksi-saksi atau ahli-ahli untuk didengar keterangannya. Pihak yang meminta dipanggilnya saksi atau ahli, harus membayar lebih dahulu kepada sekretaris Basyarnas, segala biaya pemanggilan dan perjalan atau ahli yang bersangkutan. Dalam hal pemanggilan saksi atau ahli dilakukan atas prakarsa arbiter tunggal atau arbiter majelis, maka biaya untuk itu akan dibebankan para pihak secara adil, namun terlebih dahulu dibayar oleh pemohon kepada sekretaris Basyarnas memberikan keterangan di muka sidang, para saksi atau ahli dapat diminta oleh arbiter tunggal atau arbiter majelis untuk

\footnotetext{
${ }^{34}$ Gatot Soemartono, Arbitrase danMediasi di Indonesia (Jakarta: PT Gramedia Pustaka Utama, 2006), 220.
} 
mengucapkan sumpah terlebih dahulu, bahwa saksi atau ahli itu hanya menerangkan apa yang mereka ketahui dengan sungguh-sungguh. Seluruh pemeriksaan dilakukan secara tertutup

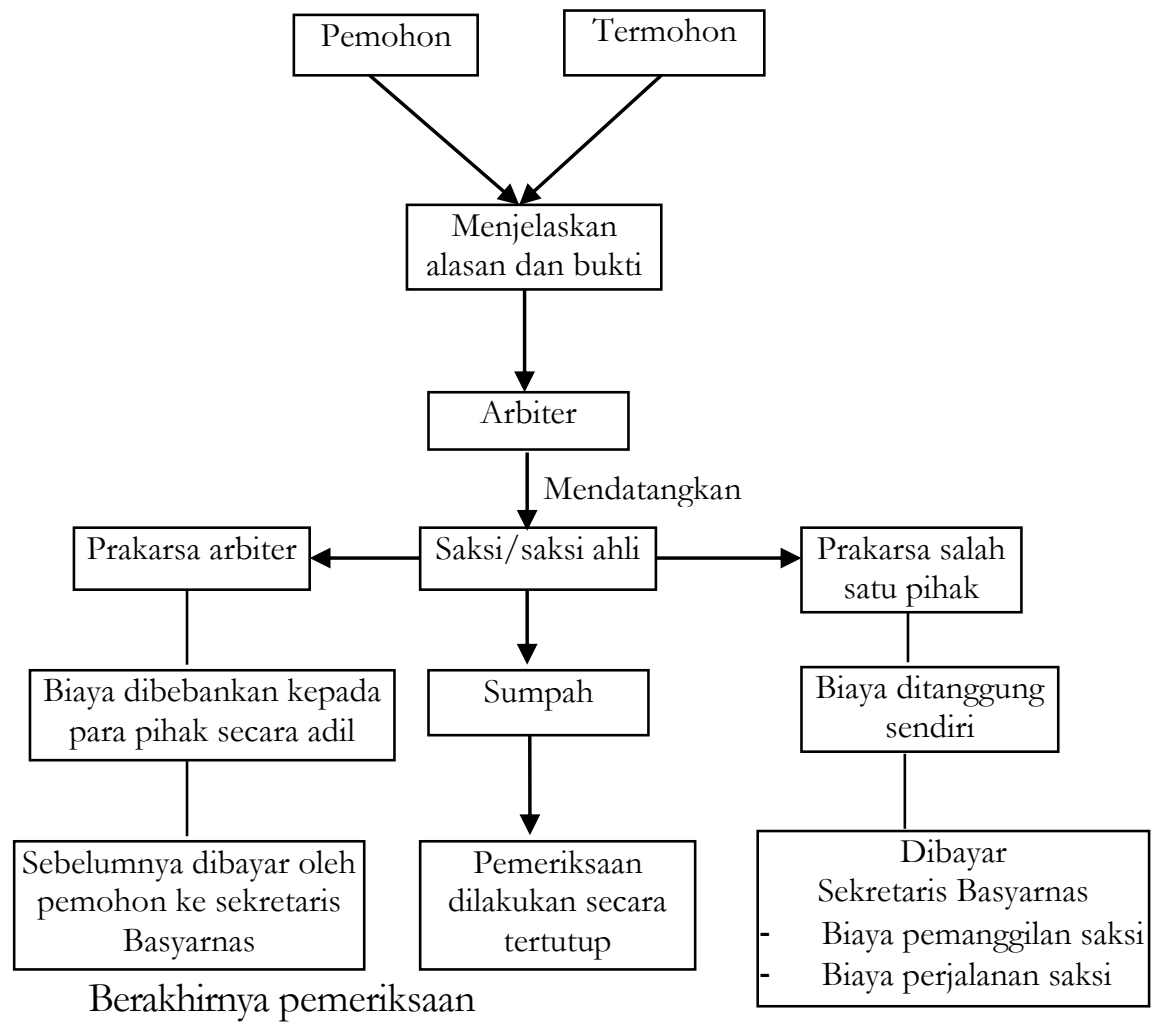

Apabila arbiter tunggal atau arbiter majelis menganggap pemeriksaan telah cukup $^{35}$, maka arbiter atau ketua arbiter majelis akan menutup pemeriksaan itu dan menetapkan suatu hari sidang guna mengucapkan putusan yang diambil. Apabila dianggap perlu arbiter tunggal atau arbiter majelis baik atas inisiatif sendiri maupun atas permintaan salah satu pihak, dapat membuka sekali lagi pemeriksaan sebelum putusan dijatuhkan. Arbiter tunggal atau arbiter majelis akan mengambil dan mengucapkan putusan dalam suatu sidang yang dihadiri oleh kedua belah pihak, dan apabila salah satu atau para pihk tidak hadir maka putusan akan diucapkan, sepanjang kepada para pihak telah disampaikan secara patut. Peradilan Arbiter tunggal atau arbiter majelis dilakukan Demi Keadilan Berdasarkan Ketuhanan Yang Maha Esa. Tiap penetapan dan putusan dimulai dengan kalimat Bismillabirrabmanirrabim, diikuti dengan Demi

${ }^{35}$ Musjtari, Penyelesaian Sengketa, 211. 
Keadilan Berdasarkan Ketuhanan Yang Maha Esa. Seluruh proses pemeriksaaan sampai dengan diucapkannya putusa Arbiter tunggal atau arbiter majelis akan diselesaikan selambat-lambatnya sebelum jangka waktu enam bulan habis, terhitung sejak tanggal dipanggilnya pertama kali para pihak untuk menghadiri sidang pertama pemeriksaan.

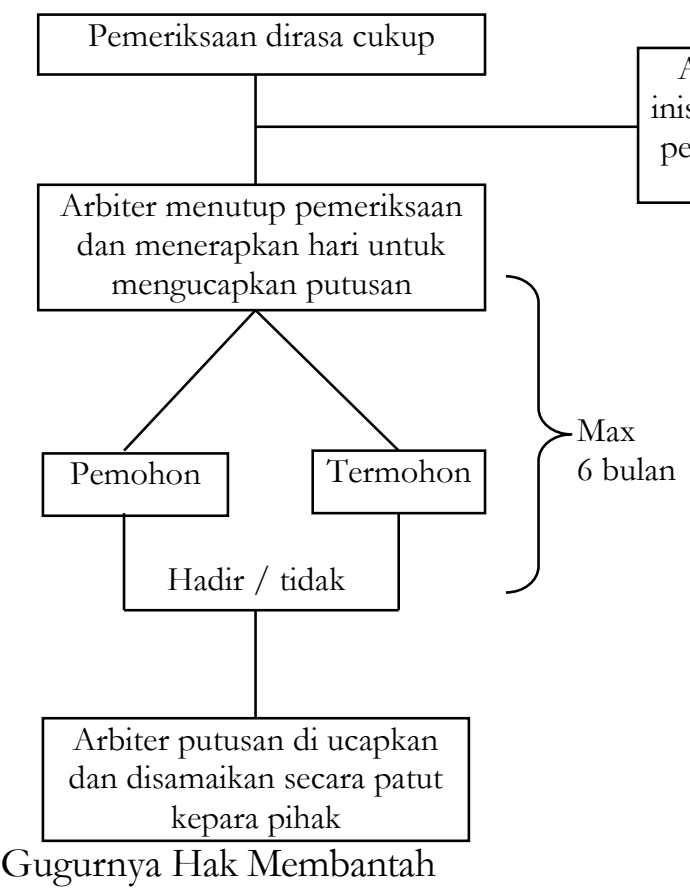

Salah satu pihak yang mengetahui adanya bagian atau ketentuan peraturan prosedur yang tidak diterapkan sebagaimana mestinya, tetapi tidak langsung mengajukan bantahan atau keberatan terhadap hal itu, dianggap menggugurkan haknya sendiri untuk mengajukan bantahan. ${ }^{36}$

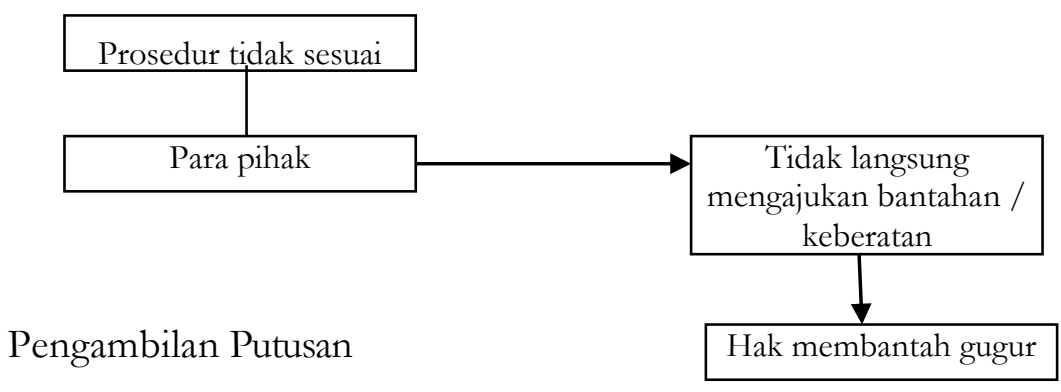

${ }^{36}$ Musjtari, Penyelesaian Sengketa, 214. 
Apabila arbiter terdiri atas tiga orang, setiap putusan atau ketetapan lain dari arbiter harus diambil berdasarkan suara terbanyak (suara mayoritas) akan tetapi apabila suara terbanyak tidak tercapai, ketua arbiter majelis dapat mengambil dan menjatuhkan putusan oleh dia sendiri dan putusan dianggap dibuat oleh semua anggota arbiter, Putusan harus memuat alasan-alasan kecuali para pihak menyetujui putusan tidak perlu memuat alasan. Arbiter tunggal atau arbiter majelis harus memutus berdasarkan pada kepatutan dan keadilan sesuai dengan ketentuan hukum yang berlaku bagi perjanjian yang menimbulkan sengketa yang disepakati para pihak. Putusan Basyarnas yang sudah ditandatangani oleh arbiter tunggal atau arbiter majelis langsung final dan mengikat (final and binding) kepada pihak yang bersengketa, dan wajib menaati serta segera memenuhi pelaksanaannya. Apabila putusan tidak dipenuhi secara sukarela seperti yang disebut pada ayat (1) putusan dijalankan menurut ketentuan yang diatur dalam Pasaj dan 639 Rv; Salinan putusan yang telah ditandatangani oleh arbiter tunggal atau arbiter majelis, harus diberikan kepada masing-masing pemohon dan termohon. Putusan tidak boleh diumumkan, kecuali disepakati oleh kedua belah pihak.

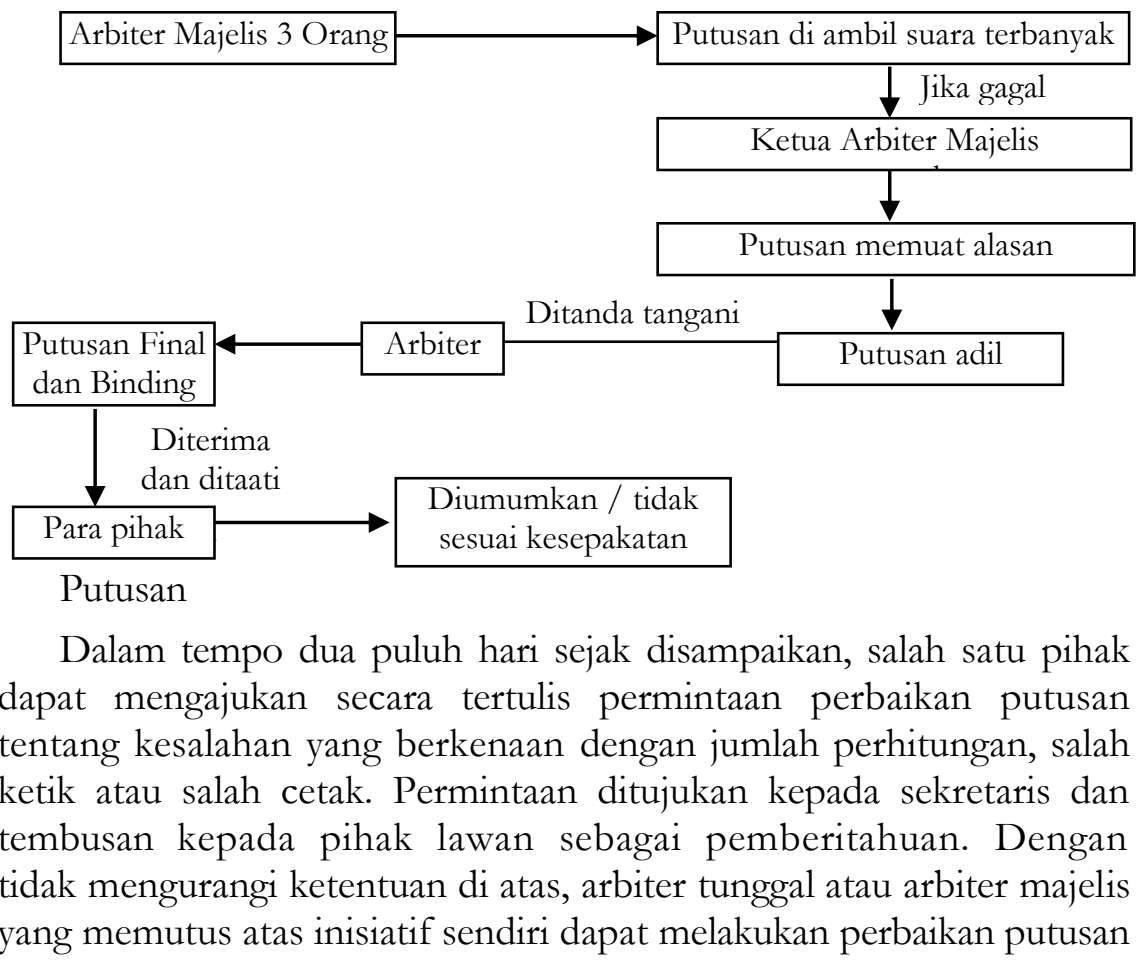


dalam waktu 20 hari sejak putusan dijatuhkan hanya mengenai hal-hal yang tersebut di atas. Perbaikan putusan harus dibuat tertulis dan ditanriatangani paling lambat dalam waktu 20 hari sejak permintaan disampaikan sekretaris kepada arbiter tunggal atau arbiter majelis, sudah memberikan perbaikan yang diminta dan perbaikan tersebut langsung menjadi bagian yang tidak terpisah dengan putusan

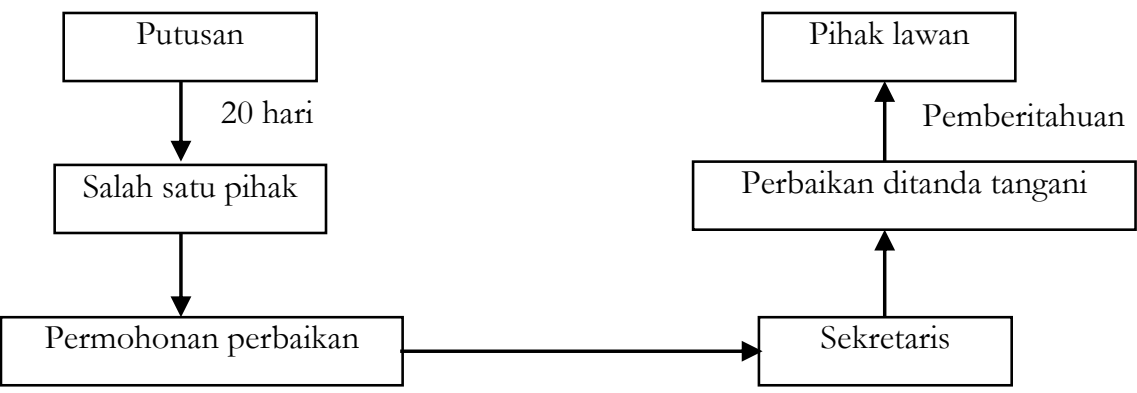

Putusan Tambahan (Additional Award)

Dalam waktu 20 hari sejak putusan diterima, pemohon dan termohon dapat mengajukan tambahan putusan. Permintaan dibuat secara tertulis ditujukan kepada sekretaris dan tembusan kepada pihak lawan tentang tuntutan yang diajukan pada saat proses pemeriksaan berlangsung tetapi arbiter tunggal atau arbiter majelis melalaikan atau mengabaikannya dalam putusan. Apabila arbiter tunggal atau arbiter majelis berpendapat permintaan tambahan putusan mempunyai alasan dan kelalaian itu dapat disempurnakan tanpa memerlukan pemeriksaan bukti atau saksi maupun pemeriksaan pemohon dan termohon ${ }^{37}$, tambahan putusan harus diselesaikan paling lambat 30 hari dari tanggal permintaan disampaikan sekretaris kepada arbiter tunggal atau arbiter majelis. Tambahan dibuat tertulis dan langsung menjadi bagian yang terpisah dengan putusan.
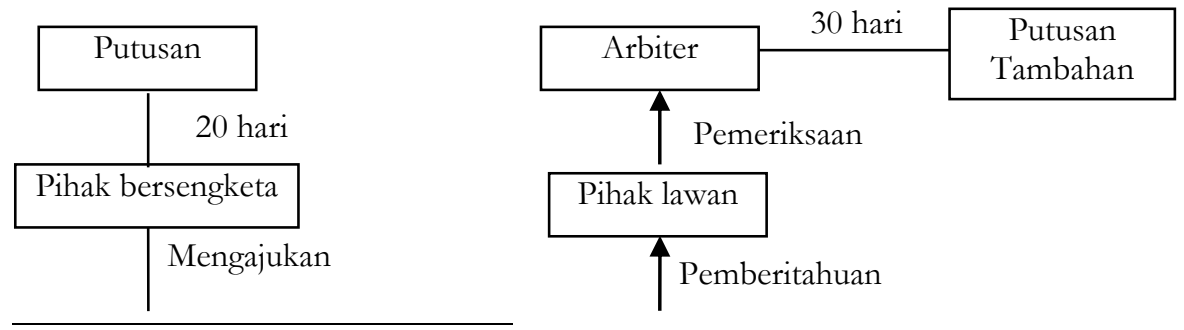

37 Pada prinsipnya penyelesaian sengketa mengutamakan dan memertamakan penyelesaian dengan adil dan islâh (perdamaian) jika terjadi kelalaian maka akan ada perbaikan kembali dalam ranah menuju kesempurnaan. Djauhari, "Penyelesaian Sengketa Bisnis Perbankan Syariah", 9. 
Tambahan putusan

Sekretaris Basyarnas

\section{Pembatalan Putusan}

Salah satu pihak dapat mengajukan secara permintaan pembatalan putusan yang disampaikan sekretaris dan tembusan kepada pihak lawan pemberitahuan, namun hal ini tidak mengurangi ke sekretaris untuk menyampaikan pemberitahuan kepada pihak lawan. Permintaan pembatalan hanya dilakukan berdasarkan salah satu alasan berikut:

1. Penunjukan arbiter tunggal atau arbiter majelis sesuai dengan ketentuan yang diatur dalam Prosedur Basyarnas, antara Putusan melampaui batas kewenangan Basyarnas

2. Putusan melebihi dari yang diminta oleh para pihak.

3. Terdapat penyelewengan di antara salah satu anggota arbiter.

4. Putusan jauh menyimpang dari ketentuan pokok peraturan prosedur Basyarnas.

5. Putusan tidak memuat dasar-dasar alasan yang menjadi landasan pengambilan putusan tanpa mengurangi ketentuan-ketentuan yang berlaku.

6. Batas waktu, tata cara dan akibat pembatalan.

Pengajuan pembatalan putusan paling lambat waktu 60 hari dari tanggal putusan diterima, kecuali mengenai alasan penyelewengan dan hal itu berlaku paling lama dalam masa 3 tahun sejak putusan dijatuhkan. Dalam tempo 40 hari sejak permintaan pembatalanditerima sekretaris, ketua dewan pengurus harus segera membentuk komite ad hoc ${ }^{38}$ yang terdiri dari tiga orang yang akan bertindak memeriksa dan memutus permintaan pembatalan. Anggota komite ditunjuk oleh ketua dewan pengurus dan salah seorang dari mereka bertindak sebagai ketua

\footnotetext{
38 Arbitrase adhoc adalah arbitrase yang didasarkan pada perjanjian arbitrase yang dibuat setelah sengketa terjadi (akta kompromis) di mana arbiter dipilih adalah arbiter bukan dari institusi yang ada, arbitrase ini tidak permanen atau tidak melembaga bersifat insidental dan jangka waktunya tertentu sampai dengan snegketa diputuskan, para pihak dapat mengatur sendiri cara-cara bagaimana pelaksanaan pemilihan arbiter, tentang prosedur, proses beracara, petugas administratif keberadaannya hanya untuk memutuskan dan menyelesaikan suatu kasus sengketa tertentu saja, setelah sengketa selesai diputus maka keberadaan arbitrase adhoc inipun lenyap dan berakhir dengan sendirinya, namun perlu ditekankan bahwa yang dijadikan pedoman dalam pemilihan dan penentuan arbiter tersebut tidak boleh menyimpang dari apa yang telah ditentukan oleh Undang-Undang. Soemartono, Arbitrase, 27.
} 
merangkap anggota dan tidak boleh ditunjuk arbiter yang ikut dalam majelis yang memutus putusan yang diminta pembatalannya.

Tata cara pemeriksaan pembatalan putusan oleh komite sama dengan tata cara pemeriksaan arbitrase yang diatur sebelumnya. Ketentuan mengenai putusan arbitrase yang diatur sebelumnya berlaku sepenuhnya terhadap putusan pembatalan. Selama pemeriksaan pembatalan berlangsung, komite dapat memerintahkan penundaan eksekusi putusan jika hal itu dianggap perlu sampai komite menjatuhkan putusan. Jika komite mengabulkan pembatalan, sengketa semula timbul kembali dan permintaan salah satu pihak dapat diajukan penyelesaian kepada Basyarnas dan untuk itu dibentuk arbiter tunggal atau arbiter majelis arbiterasi baru sesuai dengan ketentuan pembentukan dan penunjukan arbiter yang telah diatur.

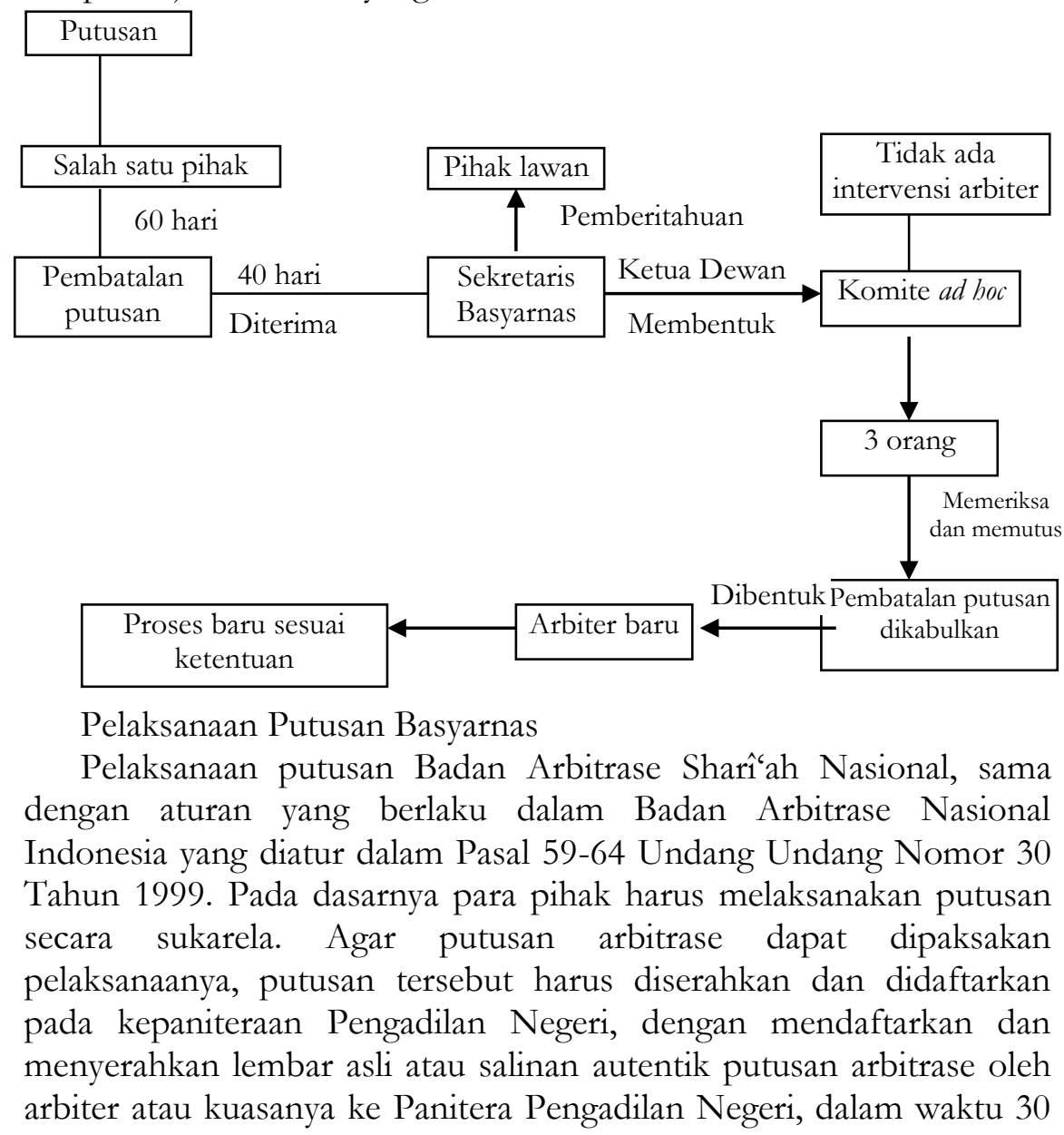


(tiga puluh) hari setelah putusan arbitase diucapkan. Putusan Arbitrase bersifat mandiri, final dan mengikat. Putusan Arbitrase bersifat mandiri, final dan mengikat (seperti putusan yang mempunyai kekeuatan hukum tetap) sehingga Ketua Pengadilan tidak diperkenankan memeriksa alasan atau pertimbangan dari putusan arbitrase tersebut. Kewenangan memeriksa yang dimiliki Ketua Pengadilan, terbatas pada pemeriksaan secara formal terhadap putusan arbitrase yang dijatuhkan oleh arbiter atau majelis arbitrase. ${ }^{39}$

Berdasarkan Pasal 62 Undang-undang Nomor 30 Tahun 1999 sebelum memberi perintah pelaksanaan, Ketua Pengadilan memeriksa dahulu apakah putusan arbitrase memenuhi Pasal 4 dan Pasal 5 (khusus untuk arbitrase internasional). Bila tidak memenuhi maka, Ketua Pengadilan dapat menolak permohonan arbitrase dan terhadap penolakan itu. sengketa para pihak yang telah terikat dalam perjanjian arbitrase. Pengadilan Negeri wajib menolak dan tidak ikut campur tangan dalam suatu penyelesaian sengketa yang telah ditetapkan melalui arbitrase. Hal tersebut merupakan prinsip limited court involvement.

Biaya administrasi dan honorarium

Apabila tuntutan sepenuhnya dikabulkan atau pendirian si pemohon seluruhnya dibenarkan, atau ditolak biaya administrasi dan pemeriksaan dibebankan kepada si pemohon. Apabila tuntutan sebagian dikabulkan, biaya administrasi dan pemeriksaari dibagi antara kedua belah pihak menurut ketetapan yang dianggap adil oleh arbiter. Honorarium bagi para arbiter selamanya dibebankan kepada kedua belah pihak, masing-masing separuh. Berdasarkan ketetapan Basyarnas No. 01/Basyarnas/9/4/2005 Tentang Biaya Arbitrase, sebagai berikut:

1. Biaya pecantuman klausul Arbitrase

Rp. 20.000,-

2. Biaya pendaftaran Konpensasi / Rekonpensi yang dihitung sebaai berikut:

Tuntutan sampai dengan:

$<$ s/d Rp 100.000.000,

Rp 100.000,-

Rp 100.000.001,- s/d Rp 300.000.000,

Rp 200.000,-

Rp 300.000.001,- s/d Rp 500.000.000,

Rp 300.000,-

Rp 500.000.001,- s/d Rp 1.000.000.000,

Rp 400.000,-

Lebih dari Rp 1.000.000.000,

Rp 500.000,-

39 Dalam hal melaksanakan putusan Basyarnas juga sama dengan ketentuan Pasal 59-64 Undang-Undang Nomor 30 tahun 1999, tentang Arbitrase dan Alternatif Penyelesaian Sengketa, 74 
3. Biaya administrasi/ pemerikasaan Konpensi / Rekonpensi yang dihitung sebagai berikut

Tuntutan sampai dengan:

$<$ s/d Rp 100.000.000, Rp 500.000,-

Rp 100.000.001,- Rp 500.000.000, Rp 1.000.000,-

Rp 500.000.001,- Rp 1.000.000.000, Rp 1.500.000,Lebih dari Rp 1.000.000.000, Rp 2.000.000,

4. Biaya Arbiter:

Tuntutan sampai dengan

Rp. 100.000.000,- s/d Rp 500.000.000,

$7 \%$

Rp 500.000.001,- s/d Rp 2.000.000.000,

$6 \%$

Rp 2.000.000.001,- s/d Rp 5.000.000.000,

$5 \%$

Rp 5.000.000.001,- s/d Rp 7.000.000.000, $4 \%$

Rp 7.000.000.001,- s/d Rp 9.000.000.000,

$3 \%$

Rp 9.000.000.001,- s/d Rp 10.000.000.000,

$2 \%$

Rp 10.000.000.001,- s/d Rp 20.000.000.000,-

$1 \%$

Rp 20.000.000.001,- s/d Rp 30.000.000.000,-

$0,90 \%$

Rp 30.000.000.001,- s/d Rp 40.000.000.000,-

$0,80 \%$

Rp 40.000.000.001,- s/d Rp 50.000.000.000,$0,70 \%$

Rp 50.000.000.001,- s/d Rp 60.000.000.000,$0,65 \%$

Rp 60.000.000.001,- s/d Rp 70.000.000.000,$0,60 \%$

Rp 70.000.000.001,- s/d Rp 80.000.000.000,$0,50 \%$

Rp 80.000.000.001,- s/d Rp 90.000.000.000,$0,40 \%$

Lebih besar dari Rp 90.000.000.000,-

$0,90 \%$ 


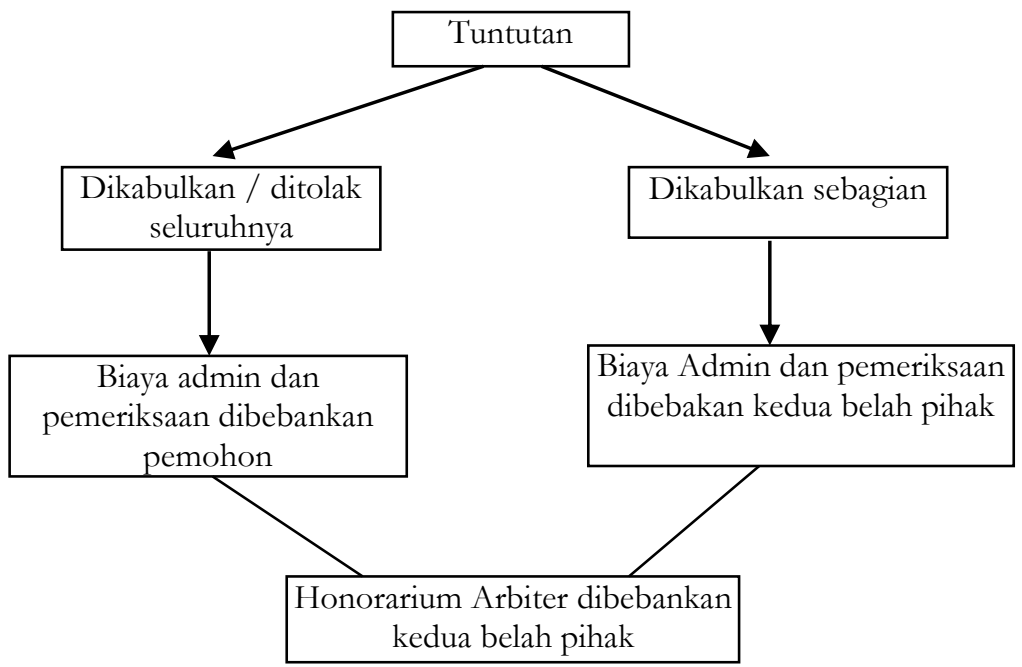

\section{Penutup}

Penyelesaian sengketa perbankan melalui jalur non-litigasi (di luar pengadilan) melalui Badan Arbitrase Sharî́ah Nasional dengan prosedur penyelesaian sengketa antara pihak Bank Sharî‘ah dengan Nasabah Bermasalah melalui Basyarnas Menurut Undang-Undang No. 30 Tahun 1999 dimulai dengan cara adanya klausul arbitrase didaftarkan ke sekretaris arbitrase. Arbiter dapat ditentukan oleh para pihak atau lembaga arbitrase, tempat dilaksanakan arbitrase dapat ditentukan oleh para pihak atau lembaga arbitrase, putusan arbitrase sesuai dengan kompetensi Basyarnas dalam menyelesaikan sengketa meliputi penyelesaian sengketa mu'âmalah atau perdata secara adil dan cepat yang timbul dalam bidang perdagangan, keuangan, industri, jasa dan sebagainya yang sesuai dengan hukum dan peraturan perundangundangan dikuasai sepenuhnya oleh pihak yang bersengketa dan para pihak sepakat secara tertulis untuk menyerahkan penyelesaian kepada Basyarnas sesuai dengan prosedur Basyarnas yang tertuang dalam UU No. 30 Tahun 1999 tentang Arbitrase dan Alternatif Penyelesaian Sengketa.

Pada praktiknya selama ini Basyarnas telah membuktikan dalam menyelesaikan perkara yang diajukan dan telah memutus perkara yang memenuhi rasa keadilan para pihak, sehingga tidak ada yang memerlukan banding, kasasi dan peninjauan kembali. Dengan demikian Basyarnas sudah melakukan penyelesaian sengketa perbankan sesuai dengan prosedur yang ada dengan proses pemeriksaan sederhana dengan putusan yang bersifat final (tidak ada 
banding, kasasi, dan peninjauan kembali) dan binding (mengikat) yang harus dipatuhi oleh semua pihak, biaya terukur relatif murah, tertutup, rahasia terjamin, suasana kekeluargaan (terhindar dari permusuhan) ukhumwah Islamîyah tetap terjalin.

\section{Daftar Rujukan}

Ahmad Nafis Wawancara. Surabaya 24 September 2012.

Ali, Abdullah Yusuf. Hukum Syariah. Jakarta: Rineka, 1992.

Arifin, Zainul. Dasar-dasar Perbankan Syariah. Yogyakarta: YPPM, 1998.

Djauhari, Achmad. "Penyelesaian Sengketa Bisnis (Perbankan) Sharî‘ah". Surabaya 4 Desember 2012.

Irmiyanto, Juli. Bank dan Lembaga Kenangan Lainnya (Jakarta: Media Ekonomia Publishing, FE. Trisakti, 1998.

Ka'bah, Rifyal. Penyelesaian Sengketa Bisnis Syariab: Sebuah Kewenangan Baru Peradilan Agama. Jakarta: Fakultas Hukum Universitas Yarsi, 2007.

Kasmir. Manajemen Perbankan (Jakarta: Raja Grafindo Persada, 2004.

Maryam Badrul Zaman, Arbitrase Islam di Indonesia (Jakarta: Rineka 1994), 64

Muhamad. Manajemen Dana Bank Syariah. Yogyakarta: Ekonisia, 2004.

Muhammad. Manajemen Bank Syariah. Yogyakarta: UPP AMPKPN, 2002.

Musjtari, Dewi Nurul. Penyelesaian Sengketa dalam Praktek Perbankan Syariah. Yogyakarta: Parama Publishing, 2012.

Nafis, Ahmad. Wawancara. Surabaya 11 Oktober 2012.

Sjabdeini, Sutan Remy. Perbankan Islam dan Kedudukannya dalam Tata Hukum Perbankan Indonesia. Jakarta: PT. Pustaka Utama Grafita, 1999.

Soemartono, Gatot. Arbitrase dan Mediasi di Indonesia. Jakarta: PT Gramedia Pustaka Utama, 2006.

Suyatno. Kelembagaan Perbankan. Jakarta: Gramedia, 1990.

Taqrir, Ahmad (Ketua Basyarnas Jawa Timur) W awancara. Surabaya 19 September 2012.

Wibowo, Edy. Mengapa Memilih Bank Syariah. Jakarta: Ghalia, 2005. Yani, Ahmad. Hukum Arbitrase. Jakarta: Intermasa, 1998. 